\title{
Feeding ecology of the deep-water aristeid crustacean Aristeus antennatus
}

\author{
J. E. Cartes, F. Sardà \\ Instituto de Ciencias del Mar, Paseo Nacional s/n, 08003 Barcelona, Spain
}

\begin{abstract}
Feeding habits and intraspecific dietary overlap in the shrimp Aristeus antennatus (Risso, 1816) were studied. A comparative analysis of the diet of the 3 main size classes was also made, taking into account sex and season as possible factors influencing diet. Dietary diversity was evaluated, and overlap and resource partitioning considered. A. antennatus preys upon the bottom-dwelling community. Stomach content analysis indicated that the diet (percent abundance) consists chiefly (near $50 \%$ ) of bivalves, the burrowing macruran Calocaris macandreae, polychaetes, amphipods, and ophiuroids. Differences were found in the diet composition of the various size classes, which exploit different resource levels, though overlap was high (Schoener index: maximum $=0.8405$, minimum $=0.7179$ ). Larger individuals root deeper into the substratum when feeding; the activity of smaller males and females is confined to the surface layer. Size class and depth of foraging in the substratum were more highly related than size class and prey size. Diet composition varied significantly between seasons, with the proportion of prey items that live buried in the substratum gradually decreasing between spring and winter (overlap index $=0.5576$ ). Dietary diversity values were consistently high in all cases and variation was slight. However, variation was higher between seasons than between sexes or size classes
\end{abstract}

\section{INTRODUCTION}

The continental slope in the Western Mediterranean between 400 and $1700 \mathrm{~m}$ supports shoals of aristeid decapod crustaceans, of which Aristeus antennatus is one of the most abundant and hence of particular interest to fisheries.

Such species undergo seasonal variations in distribution and abundance along the continental shelf and in the submarine canyons in their range (Arrobas \& Ribeiro Cascalho 1987, Tobar \& Sardà 1987). Relini \& Relini Orsi (1987) discussed possible causes of short and medium-term fluctuations in distribution.

The present study aimed to povide an initial understanding of some of the above-mentioned aspects in relation to the autecology of Aristeus antennatus in a deep-water benthic habitat. Such habitats are characterized by environmental stability and by the relative paucity of available resources (Sanders 1968, Dayton \& Hessler 1972), and these bottoms are, generally speaking, poorly known. Hessler \& Sanders (1967) noted that they present a diversity of species associated with low temperatures, high pressures, and low light levels.

Aristeus antennatus is linked to the faunal commun- ity dwelling on deep, muddy bottoms. In the Western Merditerranean such communities have been described by Carpine (1970) and Reyss (1971). Off Catalonia and southern France they are prevalent below 350 m depth (Reyss 1971).

In comparison with our knowledge of shallow water species, little is known about the feeding habits of deep-water decapod crustaceans. Most recent studies have focussed on such commercial species as lobsters (Ennis 1973, Newman \& Pollock 1974, Elner \& Campbell 1987), shrimps (Kennedy et al. 1977, Chong \& Sasekumar 1981, Cockcroft \& MacLaughlin 1986) of different species of crabs (Hill 1976, Gotshall 1977, Hughes \& Steele 1981, Paul 1981, Williams 1982, González-Gurriarán 1987). Carcinus maenas has been studied particularly thoroughly (Ropes 1968), including such aspects as optimum diet and prey size dependence, foraging strategy (Elner 1980), prey selection (Jubb et al. 1983), and prey-specific behaviour (Ameyaw-Akumfi \& Hughes 1987). Except for the similar methodology employed, there is little basis for comparing species which are systematically distant or which occupy different habitats, since most of the species studied inhabit rocky or sandy areas and hence display 
either territorial or burrowing behaviour. Aristeus antennatus is associated with dense, muddy bathyal bottoms.

Previous studies have, for the most part, only touched upon the feeding of Aristeus antennatus by listing the species identified in the stomach contents of this shrimp (Maurin \& Carries 1968, Lagardère 1972, 1977. Relini Orsi \& Würtz 1977). Lagardère (1972) noted that A. antennatus was a little-known and hard-to-study species with respect to feeding.

Spatial and temporal partitioning of the diet of Aristeus antennatus in relation to size class and sex have therefore been analyzed, in an effort to clarify these aspects of its feeding behaviour. In the process, new information concerning the behaviour of deep-water aristeid prawns has come to light and is presented, along with a new working hypothesis concerning the role of such aristeids in benthic trophic webs and in the balance of deep-water communities.

\section{MATERIAL AND METHODS}

Aristeus antennatus (Risso, 1816) were collected in trawls in the vicinity of Blanes, off Catalonia (northeastern Spain), at depths between 400 and $700 \mathrm{~m}$ (Fig. 1).

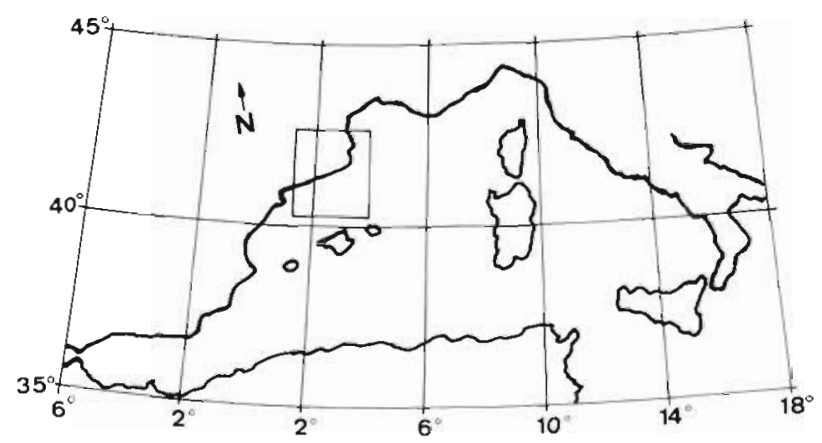

Fig. 1 Location of study area in the Western Mediterranean

Stomach contents were identified in 461 individuals ( 44 males and 417 females). Stomach fullness indices were calculated for a total of 338 stomachs of these females. Samples were taken from January 1984 to November 1986, and data were compiled for seasons of each year. The bottoms at the sampling locations (Table 1) all presented the same type of biocenosis (Carpine 1970, Reyss 1971). The size classes used in the analysis corresponded to the different year classes, taking females under $30 \mathrm{~mm}$ carapace length (CL) as small (S), those between 30 and $40 \mathrm{~mm} \mathrm{CL}$ as medium-size (M), and those over $40 \mathrm{~mm}$ CL as large (L) (Sardà \& Demestre 1987).
Table 1. Catch data

\begin{tabular}{|llcc|}
\hline Date & $\begin{array}{l}\text { Trawl } \\
\text { location }\end{array}$ & $\begin{array}{c}\text { Depth } \\
(\mathrm{m})\end{array}$ & $\begin{array}{c}\text { No. of stomachs } \\
\text { examined }\end{array}$ \\
\hline 10 Jan 1984 & Sot Malica & 460 & 15 \\
31 Jan 1984 & La Creu & 460 & 31 \\
14 Feb 1984 & La Creu & 560 & 33 \\
22 Mar 1984 & Barcelona & 690 & 24 \\
26 Mar 1984 & Arenys & 750 & 51 \\
10 Apr 1984 & Arenys & 560 & 60 \\
26 Apr 1984 & La Barana & 560 & 16 \\
15 May 1984 & La Barana & 690 & 34 \\
31 Jul 1984 & La Barana & 630 & 75 \\
2 Oct 1984 & La Barana & 610 & 43 \\
21 Nov 1984 & La Barana & 610 & 22 \\
29 Aug 1985 & La Barana & 610 & 24 \\
22 May 1986 & La Barana & 650 & 22 \\
19 Jun 1986 & La Barana & 650 & 10 \\
& & & Total 461 \\
& & &
\end{tabular}

Specimens were stored chilled and dissected ca $12 \mathrm{~h}$ after capture, and stomachs were preserved in $70^{\circ}$ alcohol. Cephalothorax length (end of the eye orbit to posterior edge of the pleon) and sex were also recorded.

Stomach contents were identified to species or to lowest possible taxonomic level. The percent frequency of occurrence $(\mathrm{O})$ and relative abundance $(\mathrm{A})$ for each type of prey were calculated for each stomach using the formulae put forward, among others, by Schoener (1970) and Bliss (1967):

$\% \mathrm{O}=$ (no. of stomachs containing a given prey item $\times 100) /$ total no. of stomachs examined

$\% A=($ no. of prey items of a given kind $\times 100) /$ total no. of prey items

Quantification of stomach contents for the abundance calculations was based on the number of pieces of telson, jaws, or other identifiable hard structure resistant to digestion.

In the authors' opinion, frequency of occurrence tends to overestimate the importance of unidentifiable matter and other small organisms such as foraminiferans. On the other hand, soft matter generally tends to be underestimated as compared to hard remains, which. stay longer in the stomach (Choi 1986). For this reason, the authors share the view expressed by Williams (1981) that, due to the difficulties involved in stomach content analysis in crustaceans, there is no one adequate, generally acceptable method capable of providing a quantitative assessment of stomach contents. Large penaeids, however, may sometimes ingest whole prey of considerable size ( $1 \mathrm{~cm}$ or larger) and thus form an exception. Nonetheless, in a number of studies on crustaceans, the percent frequency of occurrence of a given type of prey item in the diet has been used as the only readily obtainable and relatively most correct 
direct measure (MacLaughlin \& Hebard 1961, Newman \& Pollock 1974, Hill 1976, Gotshall 1977), and is likewise used here. The number of certain prey items has also been used (Hartnoll 1963, Ropes 1968, Ennis 1973, Kennedy et al. 1977). Some of these authors rejected the method of calculating prey volume.

The Schoener overlap index (Schoener 1970) was used to establish dietary affinities between the different sexes, size classes, and seasons, in terms of absolute prey abundance, given that percent occurrence is not proportional to the diet (Wallace 1981). Diets of different species can normally be regarded as significantly different when the overlap index value is below 0.6 (Orians \& Horn 1969, Zaret \& Rand 1971, Wallace 1981). However, since the dietary overlap under consideration was between different size classes of the same species in the same habitat, the authors have taken index values less than or equal to 0.8 to be indicative of significant differences.

A G-test was applied to an $\mathrm{R} \times \mathrm{C}$ matrix (Sokal \& Rohlf 1979) for the data set as a whole. A simple chisquare test was applied for comparison of diets between separate samples, and this helped determine significance levels for the overlap indices.

Lastly, diversities in the diets of the different size classes, sexes, and seasons were established using the indices of Simpson (1949) and Shannon \& Weaver (1963).

Stomach fullness was recorded as a percentage using the following scale: empty $(0-10 \%)$, moderately full $(11-40 \%)$, full $(41-70 \%)$, and very full $(71-100 \%)$.

A statistically significant number of stomachs was analyzed for each parameter in accordance with the criteria applied by Williams (1981) and Hurtubia (1983). The former held that variations in the percent frequency of occurrence of prey items should stabilize around a final value as the number of stomachs examined rises. The latter applied a similar concept using cumulative trophic diversity values. The minimum number of stomachs analyzed should be such as to ensure that a substantial percentage $(80 \%)$ of the total prey items contained in the overall list are represented. Application of Williams' method (1981) to the species under consideration gave a value of 30 stomachs, while application of Hurtubia's method (1983) yielded a value of 20 stomachs. The minimum number of stomachs examined per season was 32 .

The following additional criteria were also applied in the analysis of results:

(1) Whenever possible, a similar number of specimens was used for each of the seasons and size classes considered. Comparisons between males and females were based on specimens measuring less than $35 \mathrm{~mm}$ CL, to eliminate the size factor.

(2) Fishes and echinoderms, when present, were always counted as a single prey item per stomach, given that it is not possible to establish the exact number of such prey items ingested. Thus, the counts may be subject to a certain amount of underestimation.

(3) The presence of scales was not, in itself, taken as proof that fish had been eaten, because ingestion of scales has been known to occur in the net during capture (Jutkins \& Fleminger 1972, for Sergestes smilis).

(4) The presence of a few fragments of echinoid spicules or shells of bivalves or gastropods was ascribed to passive ingestion along with particles of the substratum. The same assumption was made in the case of foraminiferans, which make up part of the bottom sediment and which were not counted in this study. Lagardère (1972) referred to this phenomenon in Aristeus antennatus and other species.

(5) All species whose overall percentage of occurrence did not exceed $15 \%$ of the diet were grouped together under the category 'miscellaneous' and were not considered in the calculations or comparisons.

\section{RESULTS}

The most distinct components of the stomach contents of Aristeus antennatus were fragments of shells or carapaces of bivalve crustaceans or molluscs, buccal parts, pleopods, mandibles of polychaetes, and calcified fragments of echinoderms, together with fish vertebrae. Stomach content analysis showed the diet (\% abundance) of this species to consist primarily of bivalves (Table 2) (chiefly Abra longicallus), the macruran crustacean Calocaris macandreae, polychaetes, amphipods, and ophiuroids. These 5 categories accounted for $50 \%$ of the diet.

The isopod Cirolana borealis, osteichthyes, natantian decapods, euphausiids, gastropods, and cumaceans, which together accounted for a further $35 \%$ of the diet, were less important but still significant prey items. The remaining $15 \%$ of the diet consisted of prey items each of which did not exceed $3 \%$ of the total diet.

\section{Feeding and size class}

The composition of the diet (abundance) by size class is shown in Fig. 2. For large females, 50\% was accounted for by bivalves, Calocaris macandreae, polychaetes, and the isopod Carolana borealis. For medium-size females, in addition to these items, amphipods and ophiuroids were also important. For small females, ophiuroids and gastropods, together with amphipods, clearly predominated.

The importance of amphipods, gastropods, and 
Table 2. Aristeus antennatus. Frequency of occurrence (absolute and \%), and no. of prey (absolute and \%) of stomach contents by species or taxonomic group identified, by season

\begin{tabular}{|c|c|c|c|c|c|c|c|c|c|c|}
\hline & \multicolumn{5}{|c|}{ Frequency of occurrence } & \multicolumn{5}{|c|}{ No. of prey } \\
\hline & Spring & Summer & Autumn & Winter & Total & Spring & Summer & Autumn & Winter & Total \\
\hline POLYCHAETA & $51(35.6)$ & $24(30.3)$ & $27(36.9)$ & $47(70.1)$ & $149(40.8)$ & $69(8.2)$ & $25(7.4)$ & $42(12.8)$ & $71(21.1)$ & $207(10.9)$ \\
\hline NEMATODA & $1(0.7)$ & - & - & $4(5.9)$ & $5(1.4)$ & $3(0.4)$ & - & - & $6(1.8)$ & $9(0.5)$ \\
\hline \multicolumn{11}{|l|}{ CRUSTACEA } \\
\hline Unidentified & $10(6.8)$ & $8(10.1)$ & $2(2.7)$ & $6(8.9)$ & $26(7,1)$ & $10(1.2)$ & $8(2.0)$ & $2(0.6)$ & $6(1.8)$ & $26(1.3)$ \\
\hline \multicolumn{11}{|l|}{ Decapoda } \\
\hline Unidentified & $14(9.8)$ & $11(13.9)$ & $8(10.9)$ & $13(19.4)$ & $46(12.6)$ & $15(1.8)$ & $11(3.2)$ & $8(2.4)$ & $13(3.9)$ & $47(2.5)$ \\
\hline Natantia & $23(15.7)$ & $19(24.0)$ & $22(30.1)$ & $21(31.3)$ & $83(23.0)$ & $24(2.8)$ & $20(5.0)$ & $23(7.0)$ & $21(6.3)$ & $88(4.6)$ \\
\hline Unidentified & $12(8.2)$ & $4(5.3)$ & $6(8.2)$ & $10(14.9)$ & $32(8.7)$ & $12(1.4)$ & $4(1.0)$ & $6(1.8)$ & $10(2.9)$ & $32(1.7)$ \\
\hline Pasiphaea & $4(2.7)$ & $5(6.3)$ & $10(13.7)$ & $4(5.9)$ & $22(6.0)$ & $4(0.5)$ & $6(1.5)$ & $10(13.7)$ & $4(1.2)$ & $24(1.3)$ \\
\hline Sergestes & - & $8(10.1)$ & $4(5.4)$ & $3(4.4)$ & $15(4.1)$ & - & $8(1.5)$ & $4(1.2)$ & $3(0.9)$ & $15(0.8)$ \\
\hline Plesionika & $4(2.7)$ & $1(1.3)$ & $1(1.3)$ & - & $6(4.1)$ & $4(0.5)$ & $1(0.3)$ & $1(0.3)$ & - & $6(0.3)$ \\
\hline Processa & - & - & $1(1.3)$ & $2(2.9)$ & $3(0.9)$ & - & - & $2(0.6)$ & $2(0.6)$ & $4(0.2)$ \\
\hline Solenocera & $1(0.7)$ & $1(1.26)$ & - & $1(1.5)$ & $3(0.9)$ & $1(0.1)$ & $1(0.3)$ & - & $1(0.3)$ & $3(0.2)$ \\
\hline Aristeomorpha & - & - & - & $1(1.5)$ & $1(0.3)$ & - & - & - & $1(0.3)$ & $1(0.1)$ \\
\hline Acanthephyra & $1(0.7)$ & - & - & - & $1(0.3)$ & $1(0.1)$ & - & - & - & $1(0.1)$ \\
\hline Crangonidae & $2(1.4)$ & - & - & - & $2(0.5)$ & $2(0.2)$ & - & - & - & $2(0.1)$ \\
\hline \multicolumn{11}{|l|}{ Macrura Reptantia } \\
\hline $\begin{array}{l}\text { Calocaris } \\
\text { macandreae }\end{array}$ & $96(65.7)$ & $41(51.9)$ & $29(39.7)$ & $18(26.8)$ & $184(50.4)$ & $121(14.1)$ & $45(11.2)$ & $31(9.5)$ & $19(5.7)$ & $216(11.4)$ \\
\hline Alpheus & - & $3(3.8)$ & $1(1.3)$ & $9(13.4)$ & $13(3.6)$ & - & $3(0.7)$ & $1(0.3)$ & $9(2.7)$ & $13(0.7)$ \\
\hline Brachyura $^{a}$ & $1(0.7)$ & $5(6.3)$ & $4(5.4)$ & $4(5.9)$ & $14(3.8)$ & $1(0.1)$ & $5(1.3)$ & $4(1.2)$ & $4(1.2)$ & $14(0.7)$ \\
\hline Euphausiacea $^{b}$ & $27(18.5)$ & $11(13.9)$ & $3(4.1)$ & $9(13.4)$ & $50(13.7)$ & $53(6.3)$ & $12(3.0)$ & $3(0.9)$ & $12(3.6)$ & $80(4.2)$ \\
\hline \multicolumn{11}{|l|}{ Isopoda } \\
\hline Cirolana & $37(18.5)$ & $25(31.6)$ & $22(30.1)$ & $5(7.5)$ & $89(24.4)$ & $55(6.5)$ & $31(7.8)$ & $23(7.0)$ & $5(1.5)$ & $114(6.0)$ \\
\hline Gnathia & $2(1.4)$ & $1(1.3)$ & - & - & $3(0.8)$ & $2(0.2)$ & $1(0.3)$ & - & - & $3(0.2)$ \\
\hline Anthuridae & $4(2.7)$ & - & - & $1(1.5)$ & $5(1.4)$ & $4(0.5)$ & - & - & $1(0.3)$ & $3(0.2)$ \\
\hline Bopyridae & $3(2.1)$ & $3(3.8)$ & - & - & $6(1.6)$ & $4(0.5)$ & $3(0.7)$ & - & - & $7(0.4)$ \\
\hline Others & $17(11.6)$ & $4(5.1)$ & $6(8.2)$ & $2(2.9)$ & $29(7.9)$ & $18(2.1)$ & $4(1.0)$ & $6(1.8)$ & $2(0.6)$ & $30(1.6)$ \\
\hline Amphipoda $^{d}$ & $57(41.1)$ & $31(39.2)$ & $24(32.9)$ & $40(62.7)$ & $157(43.0)$ & $68(8.1)$ & $42(10.5)$ & $36(10.9)$ & $56(16.6)$ & $202(10.7)$ \\
\hline Cumacea $^{\bar{e}}$ & $43(29.4)$ & $12(15.2)$ & $6(8.2)$ & $2(2.9)$ & $65(17.8)$ & $57(6.7)$ & $16(4.0)$ & $10(3.1)$ & $2(0.6)$ & $85(4.5)$ \\
\hline \multicolumn{11}{|l|}{ Tanaidacea } \\
\hline Apseudes sp. & $7(4.8)$ & $10(12.6)$ & $2(2.7)$ & $4(5.9)$ & $23(6.3)$ & $7(0.8)$ & $10(2.5)$ & $2(0.6)$ & $4(1.2)$ & $23(1.2)$ \\
\hline Tanaiidae $^{f}$ & $12(8.2)$ & $6(7.6)$ & $1(1.3)$ & $2(2.9)$ & $21(5.7)$ & $10(1.2)$ & $5(1.3)$ & $1(0.3)$ & $2(0.6)$ & $18(1.0)$ \\
\hline Ostracoda & $3(2.1)$ & $1(1.2)$ & $2(2.7)$ & $3(4,4)$ & $9(2.5)$ & $3(0.3)$ & $1(0.3)$ & $3(0.9)$ & $3(0.9)$ & $10(0.5)$ \\
\hline Copepoda & $1(0.7)$ & - & $1(1.3)$ & $1(1.5)$ & $3(0.8)$ & $1(0.1)$ & - & $1(0.3)$ & $1(0.3)$ & $3(0.2)$ \\
\hline \multirow{2}{*}{\multicolumn{11}{|c|}{ MOLLUSCA }} \\
\hline & & & & & & & & & & \\
\hline \multirow{2}{*}{\multicolumn{11}{|c|}{ Eulamellibranchia }} \\
\hline & & & & & & & & & & \\
\hline (Unidentified) & $16(10.9)$ & $2(2.5)$ & $10(13.7)$ & $2(2.9)$ & $30(8.2)$ & $20(2.4)$ & $3(0.8)$ & $10(3.0)$ & $2(0.6)$ & $35(1.8)$ \\
\hline Abra longicallus & $73(50.0)$ & $20(25.3)$ & $11(15.1)$ & $7(10.4)$ & $111(30.4)$ & $151(17.9)$ & $35(8.7)$ & $15(4.6)$ & $8(2.4)$ & $209(11.0)$ \\
\hline Taxodonta $^{\mathrm{g}}$ & $26(19.2)$ & $11(13.9)$ & $8(10.8)$ & $9(19.3)$ & $54(14.8)$ & $28(3.3)$ & $11(2.8)$ & $10(3.0)$ & $7(2.1)$ & $56(2.9)$ \\
\hline$\overline{\text { Gastropoda }}$ & $12(8.2)$ & $17(21.5)$ & $27(36.9)$ & $3(4.4)$ & $69(18.9)$ & $15(1.8)$ & $21(5.3)$ & $46(14.0)$ & $3(0.9)$ & $85(4.5)$ \\
\hline Unidentified & $12(8.2)$ & $7(8.9)$ & $12(16.4)$ & $2(3.0)$ & $33(9.0)$ & $15(1.8)$ & $8(2.0)$ & $15(4.6)$ & $2(0.6)$ & $40(2.0)$ \\
\hline Alvania sp. & - & $12(15.2)$ & $12(16.4)$ & $1(1.5)$ & $25(6.9)$ & - & $13(3.3)$ & $23(7.0)$ & $1(0.3)$ & $37(2.0)$ \\
\hline Philinidae & - & - & $6(8.2)$ & - & $6(1.6)$ & - & - & $6(1.8)$ & - & $6(0.3)$ \\
\hline Others $^{\mathrm{h}}$ & - & - & $3(4.0)$ & - & $3(0.8)$ & - & - & $3(0.9)$ & - & $3(0.2)$ \\
\hline Sipunculida & $13(8.9)$ & $3(3.7)$ & $2(2.7)$ & $7(10.4)$ & $25(6.8)$ & $14(1.6)$ & $4(1.0)$ & $2(0.6)$ & $8(2.4)$ & $28(1.5)$ \\
\hline \multicolumn{11}{|l|}{ ECHINODERMATA } \\
\hline Ophiuroidea & $27(18.5)$ & $27(34.2)$ & $24(32.9)$ & $62(92.5)$ & $140(38.3)$ & $27(3.2)$ & $27(6.8)$ & $24(7.3)$ & $62(18.4)$ & $140(7.4)$ \\
\hline Echinoidea & $11(7.5)$ & $2(2.5)$ & $2(2.7)$ & - & $15(4.1)$ & $11(1.3)$ & $2(0.5)$ & $2(0.6)$ & - & $15(0.8)$ \\
\hline Holothuroidea ${ }^{j}$ & $4(2.7)$ & - & - & $1(1.5)$ & $5(1.4)$ & $4(0.5)$ & - & - & $1(0.3)$ & $5(0.3)$ \\
\hline \multicolumn{11}{|l|}{ CHORDATA } \\
\hline Osteichthyes & $39(26.7)$ & $24(30.3)$ & $17(23.3)$ & $16(23.9)$ & $96(26.3)$ & $39(4.6)$ & $24(6.0)$ & $17(5.2)$ & $16(4.7)$ & $96(5.1)$ \\
\hline Others $^{j}$ & $3(2.1)$ & $4(5.1)$ & $3(4,0)$ & $2(2.9)$ & $12(3.3)$ & $3(0.3)$ & $4(1.0)$ & $3(0.9)$ & $2(0.6)$ & $12(0.6)$ \\
\hline Unidentified & $8(5.5)$ & $4(5.1)$ & $4\{5.4\}$ & $2(2.9)$ & $18(4.9)$ & $8(1.0)$ & $4(1.0)$ & $4(1.2)$ & $2(0.6)$ & $18(1.0)$ \\
\hline $\begin{array}{l}\text { a Liocarcinus depura } \\
\text { Ampelisca sp. (3), P. } \\
\text { (3), Nucula sulcata } \\
\text { j Bryozoa (2), Tintinn }\end{array}$ & $\begin{array}{l}(3) ;{ }^{\mathrm{b}} \mathrm{M} \\
\text { milunata } \\
N \text {. nuclet } \\
\text { (7), rubb }\end{array}$ & $\begin{array}{l}\text { leganycuph } \\
\text { (3)i e Leuco } \\
\text { us (1) i h } \mathrm{Sp} \\
\text { per (3) }\end{array}$ & hanes no & egica, El & uphausia & " Epicar & dean larv & ae $(6)_{i}{ }^{d}$ & Iibilia a & $\begin{array}{l}\text { nata (2), } \\
\text { buloides } \\
\text { oda (1). }\end{array}$ \\
\hline
\end{tabular}




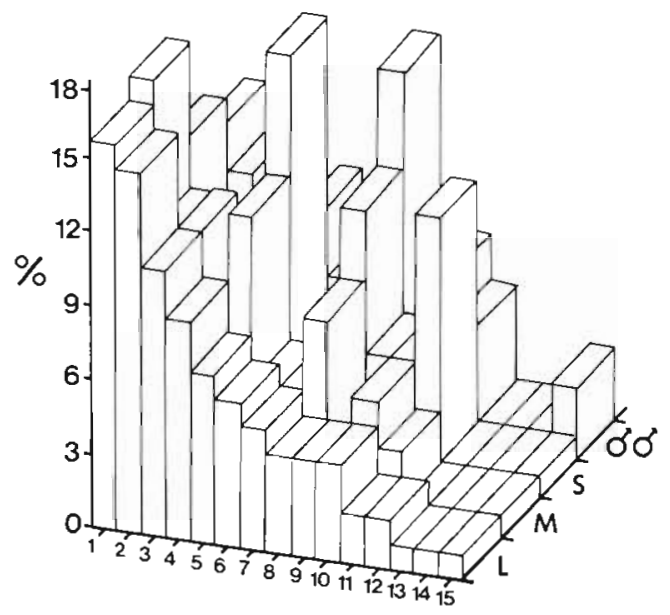

Fig. 2. Aristeus antennatus. Qualitative and quantitative diet composition for males ( $\delta$ ) and 3 size classes of females ( 9 ). $(\%)$ : no. of prey. Size classes of $A$. antennatus females: $\mathrm{S}$, small; $M$, medium; L, large. Prey items: 1, Bivalvia; 2, Calocaris macandreae; 3, Polychaeta; 4, Cirolana sp.; 5, Amphipoda; 6 , Osteichthya 7 , Euphausiacea 8 , Ophiuroidea; 9, Cumacea; 10, Natantia; 11, Gastropoda; 12, Apseudes sp.; 13, Echinoidea; 14, Brachyura; 15, Tanaidae

ophiuroids in the diet was, thus, inversely related to size. Conversely, the share of Calocaris macandreae increased with size and was particularly low in small females. The proportion of bivalves in the diet displayed the same tendency, though not as marked.

Comparisons were made to detect qualitative and quantitative differences in the diets of the various size classes and sexes (small, $S$; medium, $M$; large, $L_{\text {; }}$ males, $\left.\delta^{*}\right)$. No significant differences between the diets for the various size classes were found at the probability levels employed $(p=0.05$ and $p=0.01$ ) when treating the data set as a whole (see Materials and methods'). However, when the diets of any 2 individual size class were compared by means of a chisquare test, significant differences $(p=0.05)$ were

Table 3. Aristeus antennatus. Chi-square and overlap index values between stomach contents parameters ( + : significant difference; - : non-significant difference)

\begin{tabular}{|c|c|c|c|c|}
\hline \multicolumn{2}{|c|}{ Comparison } & \multicolumn{2}{|c|}{$\begin{array}{c}\chi^{2} \\
\chi^{2} \\
(p=0.05)(p=0.01)\end{array}$} & Schoener \\
\hline \multirow[t]{3}{*}{ Size } & qq large/medium & - & - & $0.8405(-)$ \\
\hline & 우 medium/small & + & - & $0.8054(+)$ \\
\hline & q large/small & + & + & $0.7197(+)$ \\
\hline Sex & $99<35 \mathrm{~mm} \mathrm{CL} / 38$ & - & - & $0.8387(-)$ \\
\hline \multirow[t]{4}{*}{ Season } & Spring/summer & + & - & $0.7856(+)$ \\
\hline & Summer/autumn & + & - & $0.8438(-)$ \\
\hline & Autumn/winter & + & + & $0.6702(+)$ \\
\hline & Winter/spring & + & + & $0.5576(+)$ \\
\hline
\end{tabular}

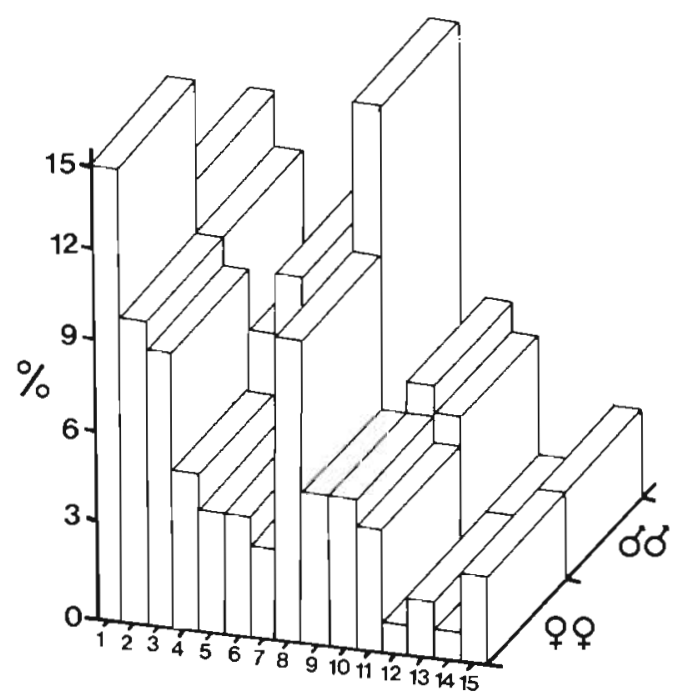

Fig. 3. Aristeus antennatus, Qualitative and quantitative diet composition for males and females. Legend as Fig. 1

obtained between all groups except between the medium and large size classes (Table 3).

\section{Feeding and sex}

The diets of males and females were compared (Fig. 3) using females with a cephalothorax size of less than $35 \mathrm{~mm}$ (the maximum size observed in males) in order to prevent any bias due to size differences.

Predominant prey items in males were ophiuroids, bivalves, Calocaris macandreae, amphiphods, and polychaetes, in approximately equal proportions (Fig. 3). The diet of females consisted of the same prey items, but in a different order of importance. Although the percent frequency of occurrence of all prey items was generally the same or higher in females as compared to males, the absolute abundance of each item. was not quantitatively different for the 2 sexes. This was shown by means of a chi-square test, which yielded no significant difference $(p=0.05$ and $p=$ $0.01)$, and by the high overlap index value between the sexes $(0.8387)$ (Table 3$)$.

\section{Feeding and season}

Bivalves and Calocaris macandreae predominated in spring (these 2 items accounting for ca $40 \%$ of the diet; Fig. $4 \mathrm{~A}$ ). These same 2 prey items continued to prevail in summer, although their share in the diet dropped to $25 \%$. The share of other prey items, such as amphipods and the isopod Cirolana borealis, grew in summer. An important shift in the diet began in autumn, when the share of gastropods and polychaetes rose considerably, 

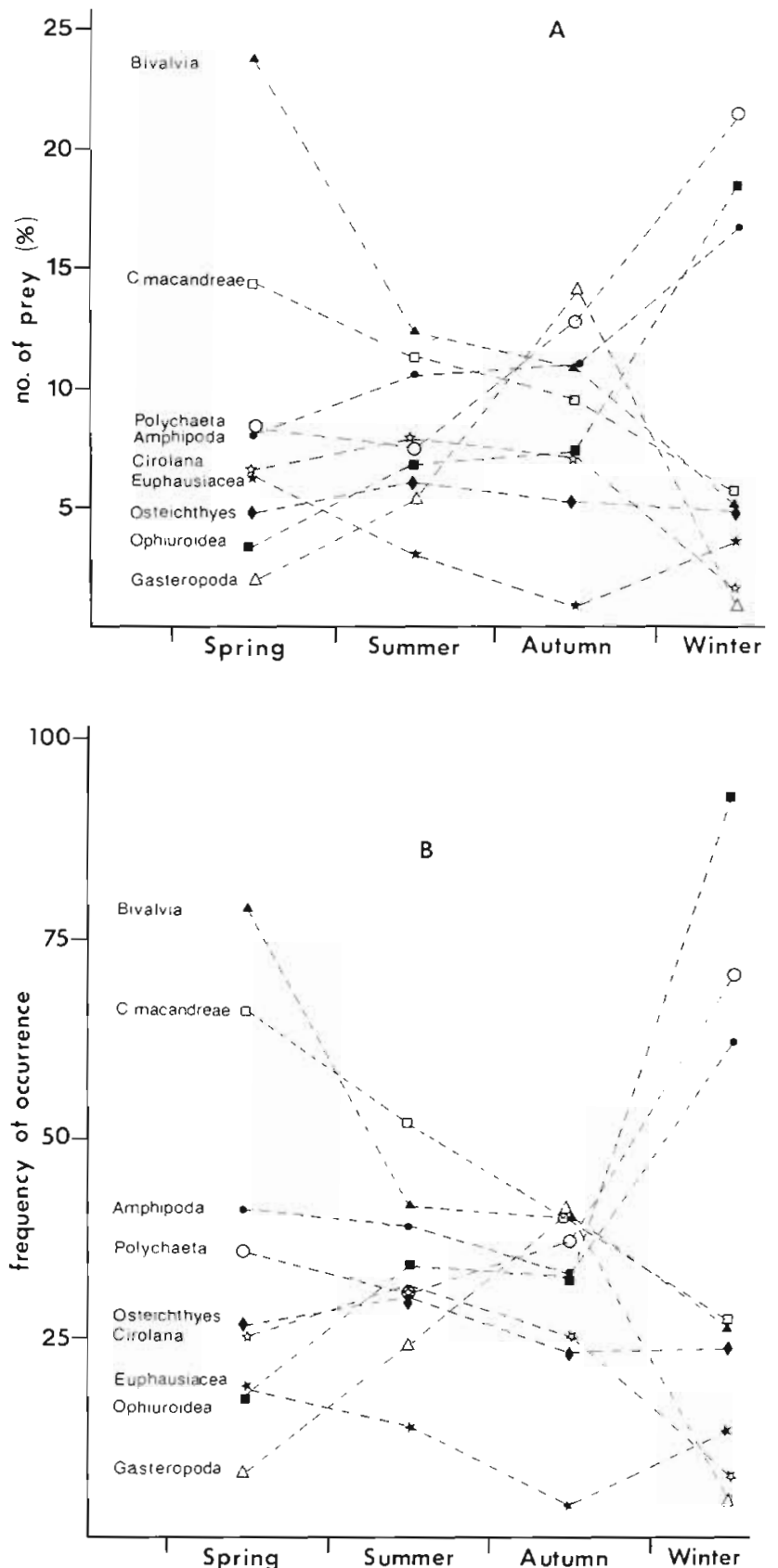

Fig. 4. Ansteus antennatus. (A) Seasonal percent number of prey: (B) seasonal percent frequency of occurrence

from 5 to $20 \%$ of the total diet. Another dominant prey item, ophiuroids, made its appearance in winter, and, along with polychaetes and amphipods, accounted for ca $60 \%$ of the diet.

In consequence, there was a progressive shift in the make-up of prey items in the diet between summer and autumn, although it was much more gradual than the abrupt change between winter and spring, when maximum differences in dietary composition were observed (Table 3).
The overlap index value between spring and summer was 0.7850 , whereas the value between summer and autumn was slightly higher $(0.8438)$. The lowest values (corresponding to sharper changes in the diet) were found for autumn-winter (0.6702) and winterspring $(0.5576)$.

The frequency of occurrence of the different prey items over the year coincided fully with the results for the number of prey items outlined above (Fig. 4B). Ophiuroids were present in the vast majority of stomachs examined $(90 \%)$ in winter. No other prey item even approached this percentage.

\section{Stomach fullness}

Stomach fullness by season and size class was compared on the basis of the criteria set out in Materials and methods' (Fig. 5). The number of empty stomachs ranged between 5 and $25 \%$ of the total, indicative of a high average feeding rate or a slow digestion rate (typical of animals feeding on calcified prey)

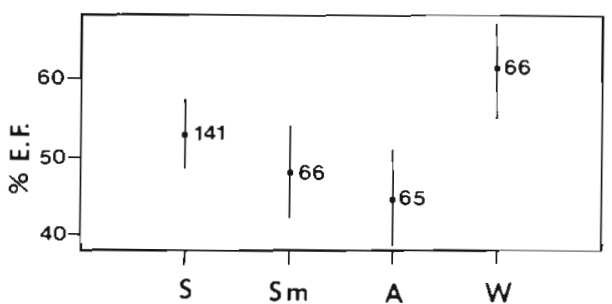

Fig. 5. Aristeus antennatus. $95 \%$ confidence intervals for stomach fullness factor (E. F.) means by season. S: spring; Sm: summer; $A$ : autumn; $W$ : winter. Numbers: number of stomachs sampled

Analysis of variance (ANOVA) was used to compare the influence of the different size classes and seasons on stomach fullness. A significant effect was found $(p=$ 0.01 ) only in the case of seasonality; Fig. 5 shows higher stomach fullness values during winter. No interaction between these 2 parameters was observed.

\section{Diversity}

The diversity values for the various parameters are presented in Table 4. Diversity was observed to be generally high, as is considered typical for deep-water communities, and observed differences were relatively small. No appreciable differences were observable between the different size classes or sexes.

Summer was the season presenting the highest dietary diversity. Conversely, winter presented the lowest values. These results are in agreement with the results for prey item variability shown in Fig. 6. Fig. 6A 
Table 4. Aristeus antennatus. Diversity index values of stomach contents by size class, sex and season

\begin{tabular}{|c|c|c|c|}
\hline Factor & & Shannon-Weaver & Simpson \\
\hline \multirow[t]{3}{*}{ Size } & q large & 3.8178 & 0.9034 \\
\hline & Q\& medium & 3.7782 & 0.9022 \\
\hline & 9 small & 3.7695 & 0.9014 \\
\hline \multirow[t]{2}{*}{ Sex } & $\delta \delta$ & 3.6943 & 0.9070 \\
\hline & $99<35 \mathrm{~mm} \mathrm{CL}$ & 3.7660 & 0.9057 \\
\hline \multirow[t]{4}{*}{ Season } & Spring & 3.6401 & 0.8830 \\
\hline & Summer & 3.7910 & 0.8958 \\
\hline & Autumn & 3.7053 & 0.9174 \\
\hline & Winter & 3.4733 & 0.8688 \\
\hline
\end{tabular}

depicts the relationship expressed as the ratio between the mean number of prey items and the mean number of different kinds of prey items per stomach by season and by size class.

The seasonal diversity index values were higher in spring and winter than in the other 2 seasons. This indicates that the prey items consumed in spring and winter were more consistently the same type (bivalves Calocaris macandreae, Cirolana borealis, etc.), as demonstrated by the frequency of occurrence of these items in the stomachs. The diet was less repetitive in summer and autumn. However, the differences between the index values for the different seasons in no case exceeded $13 \%$, and the significance of such
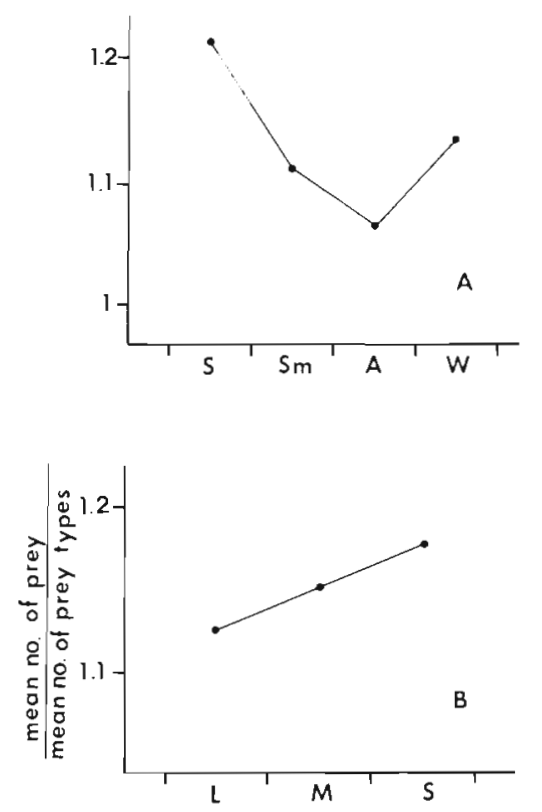

Fig. 6. Aristeus antennatus. Relationship between mean number of prey and mean number of prey types per stomach (A) by season ( $S$, spring; $S m$, summer; $A$, autumn; $W$, winter); and (B) by size class ( $L$, large; $M$, medium; $S$, small) differences is questionable; differences between size classes (Fig. 6B) were also negligible.

\section{DISCUSSION}

Results indicate that the diet of Aristeus antennatus consists entirely of benthic organisms and that these can be divided into 3 main categories: (1) organisms that live completely or partially buried, digging out small galleries in the substratum (Calocaris macandreae, polychaetes, bivalves, etc.); (2) organisms that dwell on or just beneath the surface of the substratum (amphipods, isopods, gastropods, ophiuroids, etc.); (3) bathypelagic organisms that, as a result of vertical migrations, may dwell close to the bottom during part of the day (Pasiphaea, Processa, Sergestes, euphausiids, Meganyctiphanes norvegica, and fish).

Prey items ingested infrequently or as detritus can be placed into Categories 2 or 3. Other authors have assigned fish to these categories (Lagardère 1977). We note the total absence of pelagic organisms in the diet of Aristeus antennatus in contrast to the diet of pelagicdwelling natantian decapods (Lagardère 1972. Hefferman \& Hopkins 1981),

Marine invertebrate communities in deep-water habitats normally exhibit low levels of competition and predation, even though food is not overly abundant (Grassle \& Sanders 1973, Macpherson 1981, Blaber et al. 1987). Population structure tends to adopt a form that will minimize interspecific competition (AmeyawAkumfi \& Hughes 1987) or intraspecific competition between size classes (Keast 1978), in order to optimize energy utilization through balanced partitioning of available resources. This is often responsible for size segregation, or for sex segregation when size is sexdependent (Peters \& Grubb 1983). Aristeus antennatus would appear to conform to this pattern, since the differing feeding habits of the various size classes would seem to be related to their physical ability to dig up or root in the substratum.

Medium and large females exhibit a greater propensity to feed on species with more pronounced burrowing behaviour (Calocaris macandreae, bivalves), whereas smaller females display a preference for prey items that dwell on or near the surface of the substratum (amphipods, ophiuroids, etc.).

Males (which in this species belong to the smaller size classes) display a greater affinity with the feeding habits of small females than with those of the other size classes. Thus, there is a gradation between the diets of the various sizes, evidenced by variation in the percent share of the different taxonomic groups (bivalves, amphipods, ophiuroids, cumaceans, tanaidaceans, and gastropods), that can be related to population structure 
and to the morphological characteristics of the different size classes and sexes (Burukovskii 1969, 1972, Burukovskii \& Romenskii 1972). The authors agree with Relini Orsi \& Würtz (1977) that Aristeus antennatus is a 'slow hunter' which forages in the substratum, unlike shrimp Parapenaeus longirostris (Penaeidae) and, more particularly, Aristeomorpha foliacea (Aristeidae), an overlapping species that is a more active predator hunting larger prey.

Differentiation in the feeding behaviour of the sexes has already been seen to be linked primarily to individual size, in view of the distinctive, size-related sexual dimorphism in this species. Differences in diversity were found between males and large females but not between males and females the same size, in which the only difference detected was in the absolute number of prey items per stomach, which was higher in females.

Dietary diversity did not vary between size classes or sexes, and values were in all cases rather similar. In consequence, this prawn does not seem to develop a diet directed at more specific sectors of the available resources as it grows larger, although it does become more specialized with respect to the level of substratum searched. Thus, in view of the fact that bathyal bottoms present a high degree of diversity of available food resources, Aristeus antennatus can be considered a random feeder.

Prey size selection may be a relevant factor, since smaller prey such as amphipods predominate in the diet of small prawns, while the isopod Cirolana borealis prevails in the diet of medium and large females. Macpherson (1981) stated that certain demersal fish exhibit size selection behaviour in their predation pattern on or just above the bottom. He further pointed out that this was not the case with fish that hunted by rooting up the substratum, in which location of prey occurs at random during rooting. The possible relationship between the size of Aristeus antennatus and Calocaris macandreae size was analyzed in order to verify this aspect of the dietary habits of deep-water prawns. This prey item was used because it is the most important diet component and because it leaves clearly identifiable remains in the stomach. C. macandreae size was taken into account in stomach content analysis only in those cases in which the size could be accurately determined (Table 5). Results indicate that $A$. antennatus predation on C. macandreae was not size-dependent, as might be expected for a burrowing prey type. It thus seems reasonable to assume that the prevalence of this species in the diet of medium and large females is due to the ability of these size classes to forage more deeply in the substratum.

Rooting behaviour would appear to be more intense in spring and summer, and lower in autumn and winter. Instead of the prey items normally taken up to
Table 5. Aristeus antennatus. Percentage of small (S), large (L), and indeterminate size (I) Calocaris macandreae in the stomachs of females by size class

\begin{tabular}{lrcc|}
\hline & \multicolumn{3}{c|}{ Calocaris macandreae } \\
A. antennatus & $\mathrm{S}$ & $\mathrm{L}$ & $\mathrm{I}$ \\
\hline Small & 4.16 & 29.16 & 66.68 \\
Medium & 17.64 & 23.53 & 58.83 \\
Large & 7.47 & 28.08 & 64.45 \\
\hline
\end{tabular}

that time (bivalves, Calocaris macandreae), a preference emerges for prey items that live in the surface layer, such as ophiuroids, polychaetes, and amphipods, whose share in the diet grows in autumn and, in winter, entirely displaces prey obtained by rooting behaviour. Cockcroft \& MacLaughlin (1986) reported that the juveniles and adults of littoral penaeids occupied distinctly separate subhabitats and that their feeding habits clearly reflected resource availability in each season in the habitat occupied.

Two possible explanations for this change in diet are prey availability and seasonal prawn shoal migration. Studies on the feeding habits of various fish species in the area (Macpherson 1979, 1981) have indicated that the populations of ophiuroids and polychaetes do not fluctuate to any significant extent during the year. No studies dealing with temporal variations in benthic community structure in the study area are known. However, Aristeus antennatus employs these food sources above all in winter, which would seem to indicate that they are used as secondary resources and that it prefers Calocaris macandreae and bivalves. Seasonal shoal migrations would mean that $A$. antennatus predation would be directed at slightly different communities in different seasons of the year.

The winter increase in the stomach fullness index is difficult to explain. On the one hand, it might logically be attributed to increased feeding activity to accumulate resources for the reproductive processes. On the other hand, it might also be ascribable to the change in diet observed in winter, with the larger share of ophiuroids in the diet, since these organisms present hard structures that are digested more slowly and might thus affect the results. Further consideration of these possibilities is beyond the scope of the present paper but would be an appropriate subject for future work.

The diversity index values yielded relatively nonsignificant differences between seasons. The lowest values (3.4773 and 0.8688; Table 4) were obtained in winter, very likely as a consequence of the substantial reduction in the share of prey items that live more deeply buried in the substratum in favour of ophiuroids, polychaetes, and amphipods from the sur- 
face layer. At this time of year the prawn shoals are located at shallower depths, where the diversity of available resources should be greater, which suggests that the prawn tends to select its prey whenever it has the opportunity to do so.

According to Keast (1978), dietary overlap is dependent upon available resources. However, when resources are fluctuating, overlap is not always an indicator of a specific increase in competition. Furthermore, in the case of this prawn, the diversity index values remained at high levels throughout the year, suggesting that there is no seasonal specialization due to fluctuations in available resource levels.

In conclusion, exploitation of food resources by the deep-water benthic prawn Aristeus antennatus is based on significant differences in diet between the various size classes and seasons. The different size classes exploit separate levels of the available resources in the substratum as a function of the rooting depth employed when foraging during normal feeding activity, but prey size does not appear to bear any relationship to predator size. The higher stomach fullness values detected during winter pose questions for future research.

Acknowledgements. The authors express their appreciation to Dr J. Lleonart for his assistance in processing the data and to Dr E. Macpherson for his critical review of the manuscript. They likewise thank Drs L. Relini Orsi and P. Abello for their help in stomach content analysis and Messrs R. Tobar and J. Pinar for their technical assistance. Mr R. Sacks prepared the English translation. This study was supported by research grants provided by CIRIT (Generalitat of Catalonia) and La Caixa de Barcelona (Obra Social) and by colloboration afforded by the BATIMAR research project 'Exploración y prospección de los recursos potenciales por debajo de los $1000 \mathrm{~m}$ en el Mediterráneo Ibérico' (Survey and exploration of potential resources below $1000 \mathrm{~m}$ in the Mediterranean off the Iberian Peninsula).

\section{LITERATURE CITED}

Ameyaw-Akumfi, C., Hughes, R. N. (1987). Behaviour of Carcinus maenas feeding on large Mytilus edulis. How do they assess the optimal diet? Mar. Ecol. Prog. Ser. 38 (3): 213-216

Arrobas, I. Ribeiro-Cascalho, A. (1987). On the biology and fishery of Aristeus antennatus (Risso, 1816) on the south Portuguese coast. Investigación pesq. 51 (Suppl. 1): 233-244

Blaber, S. J., Bulman, C. M. (1987). Diets of fishes of the upper continental slope of eastern Tasmania: content, calorie values, dietary overlap and trophic relationships. Mar. Biol. 95: 345-357

Bliss, C. I. (1967). Statistics in biology. MacGraw Hill, New York

Burukovskii, R. N. (1969). On the bathymetric distribution and feeding of the shrimp Parapenaeus longirostris (Lucas). Coun. Meet. int. Counc. Explor Sea C. M.-ICES/K: 6, 1-7

Burukovskii, R. N. (1972). The function of the rostrum in shrimps. Fish. Res. Atl. Ocean. Trudy AtlantNIRO. 42: $176-179$
Burukovskii, R. N., Romenskii, L. L. (1972). The rostrum variability in the shrimp Aristeus varidens (Decapoda, Penaeidae). Fish Res. Atl. Ocean, Trudy AtlantNIRO. 42: $156-160$

Carpine, Ch. (1970). Ecologie de l'étage bathyal dans la Méditerranée occidentale. Mém. Inst. océanogr Monaco 2: $146 \mathrm{p}$

Choi, S. C. (1986). Natural diet and feeding habits of the crabs Liocarcinus puber and L. holgatus (Decapoda, Brachyura, Portunidae). Mar. Biol. 31: 87-99

Chong, V C., Sasekumar, A. (1981). Food and feeding habits of the White Prawn Penaeus merguiensis. Mar. Ecol. Prog. Ser. 5: 185-191

Cockcroft, A., MacLaughlin, A. (1986). Food and feeding habits of the surf zone Penaeid prawn Macropetasma africanus (Balss). P.S.Z.N.I. Mar. Ecol. 7 (4): 345-358

Dayton, P. K., Hessler, R. R. (1972). Role of biological disturbance in maintainings diversity in the deep sea. Deep Sea Res. 19: 199-208

Elner, R. W. (1980). The influence of temperature, sex and chela size in the foraging strategy of the shore crab Carcinus maenas (L.). Mar. behav. Physiol. 7: 15-24

Elner, R. W., Campbell, A. (1987). Natural diets of lobster $H$. americanus from ground and macroalgal habitats off southwestern Nova Scotia, Canada. Mar. Ecol. Prog. Ser. 37 (2-3): 131-140

Elner, R. W. Hughes, R. N. (1978). Energy maximization in the diet of the shore crab Carcinus maenas J. Anim. Ecol. 47 : $103-116$

Ennis, G. P. (1973). Food, feeding and condition of lobster Homarus americanus, throughout the seasonal cycle in Bonavista Bay, Newfoundland. J. Fish. Res. Bd Can. 30: 1905-1909

González-Gurriarán, E. (1987). Introducción a la alimentación en la nécora Macropipus puber (L.) (Decapoda, Brachyura). Boln Inst. esp. Oceanogr. 4: 81-93

Gotshall, D. W. (1977). Stomach contents of northern California Dungeness crabs Cancer magister. Calif. Fish Game 63: $43-51$

Grassle, J. F., Sanders, H. L. (1973). Life histories on the role of disturbance. Deep Sea Res. 20: 643-659

Hartnoll, R. G. (1963). The biology of Manx spider crabs. Proc. zool. Soc. Lond. 141: 423-496

Hefferman, J. J., Hopkins, T L. (1981). Vertical distribution and feeding of the shrimp genera Gennadas and Bentheogenema in the eastern Gulf of Mexico. J. crust. Biol. 1 (4): 461-473

Hessler, R., Sanders, H. (1967). Faunal diversity in deep-sea. Deep Sea Res. 14 (1): 65-78

Hill, B. J. (1976). Natural food foregut clearance-rate and activity of the crab Scylla serrata. Mar. Biol. 34(1): 109-116

Hughes, R. N., Steele, R. (1981). Size selection of mussels by the blue crab Callinectes sapidus: energy maximizer or time minimizer? Mar. Ecol. Prog. Ser. 6: 83-89

Hurtubia, J. (1983). Trophic diversity measurements in sym patric predatory species. Ecology $54: 885-890$

Jubb, C. A., Hughes, R. N., Rheinallt, A. P. (1983). Behavioral mechanism of size-selection by crab $C$. maenas (L.) feeding on mussels Mytilus edulis. J. exp. mar. Biol. Ecol. 66: $81-87$

Jutkins, D. C., Fleminger, A. (1972). Comparison of foregut contents of Sergestes smilis obtained from net collections and albacore stomachs. Fish. Bull. U.S. 70: 217-223

Keast, A. (1978). Feeding interrelations between age-groups of punpkinseed (Lepomis gibbosus) and comparisons with bluegill (L. macrochirus). J. Fish. Res. Bd Can. 35: 12-27

Kennedy, F. S., Crane, J. J., Schlieder, R. A., Barber, D. G. 
(1977). Studies of the rock shrimp Sicyonia brevirostris, a new fishery resource on Florida's Atlantic shelf. Fla mar. Res. Publs 27: 1-65

Lagardère, J. P. (1972). Recherches sur I'alimentation des crevettes de la pente continentale marocaine. Tethys 3 (3): $655-675$

Lagardère, J. P. (1977). Recherches sur la distribution verticale et sur l'alimentation des crustacés decapodes benthiques de la pente continentale du Golfe de Gascogne. Bull. Cent. Étud. Rech. scient., Biarritz 11 (4): 367-440

Macpherson, E. (1979). Ecological overlap between macrourids in the Western Mediterranean Sea. Mar Biol. 53: 149-159

Macpherson, E. (1981). Resource partitioning in a Mediterranean demersal fish community. Mar. Ecol. Prog. Ser. 4: $183-193$

Maurin, C., Carries, C. (1968). Note preliminaire sur l'alimentation des creveltes profondes. Rapp. P.-v. Réun. Cons. perm. int. Explor. Mer 19 (2): 155-156

McLaughlin, P. A., Herbard, J. F. (1961). Stomach contents of the Bering Sea King crabs. Bull. int. N. Pacif. Fish. Commn 5: $5-8$

Newman, G. G., Pollock, D. E. (1974). Growth of the rock lobster Jasus lalandei and its relationship to benthos. Mar Biol. 24: 339-396

Orians, G. H., Horn, H. S. (1969). Overlap in foods and foraging of four species of blackbirds in the pathodes of Central Washing. Ecology 50: 930-938

Paul, R. K. G. (1981). Natural diet, feeding and predatory activity of the crabs Callinectes arcuatus and $C$. toxones (Decapoda, Portunidae). Mar. Ecol. Prog Ser. 6: 91-99

Peters, W. D., Grubb, J. C. Jr. (1983). An experimental analysis of sex-specific foraging in the downy woodpecker Picoides pubescens. Ecology 64: 1437-1443

Relini, G., Relini Orsi, L. (1987). The decline of red shrimps stocks in the Gulf of Genoa. Investigación pesq. 51 (Supp) 1): $245-260$

Relini Orsi, L., Würtz, M. (1977). Aspetti della rete trofica

This article was submitted to the editor batiale riguardanti Aristeus antennatus (Risso, 1816). Atti IX Congr. naz. Soc. ital. Biol. mar.: 389-398

Reyss, D. (1971). Les canyons sous-marins de la mer Catalane, le rech du Cap et le rech Lecaze-Duthiers. III. Les peuplements de macrofaune benthique. Vie Milieu 22 (3B): $529-613$

Ropes, J W (1968). The feeding habits of the green crab $C$. maenas. Fish. Bull. U.S. 67: 183-203

Sanders, H. L. (1968). Marine benthic diversity: a comparative study. Am. Nat. 102: 243-282

Sardà, F., Demestre, M. (1987). Estudio biológico de la gamba Aristeus antennatus (Risso, 1816) en el Mar Catalán (NE de España). Investigación pesq. 51 (Suppl. 1): 213-232

Schoener, T W (1970). Nonsynchronous spatial overlap of lizards in patchy habitats. Ecology 51 (3): 408-418

Shannon, C. E., Weaver, $W$ (1963). The mathematical theory of communication. Press Urbana. Univ. Illinois

Simpson, E. H. (1949). Measurements on diversity. Nature, Lond. 163: 688

Sokal, R. R., Rohlf, F. J. (1979). Biometria. Principios y métodos estadísticos en la investigación biológica. Blume Ediciones, Madrid

Tobar, R., Sardà, F. (1987). Análisis de las capturas de gamba rosada, Aristeus antennatus (Risso, 1816) en los últimos decenios en Cataluña. Inf. Téc. Inst. Cien. Mar. Barcelona 142: $1-20$

Wallace, R. K. Jr. (1981). An assessment of diet-overlap indexes. Trans. Am. Fish. Soc. 110: 72-76

Williams, M. J. (1981). Methods for analysis of natural diet in portunid crabs (Crustacea, Decapoda, Portunidae). J. exp mar. Biol. Ecol. 52: 103-113

Williams, M. J. (1982). Natural food and feeding in the comercial sand crab Portunus pelagicus Linnaeus, 1766 (Crustacea, Decapoda, Portunidae) in Moreton Bay, Queensland. J. exp. mar. Biol. Ecol. 59: 165-176

Zaret, T. M., Rand, A. S. (1971). Competition in tropical stream fishes: support for the competitive exclusion principle. Ecology 52: 336-342

Manuscript first received: August 26, 1988

Revised version accepted: March 29, 1989 